\title{
Emotions in Covid-19 Twitter discourse following the introduction of social contact restrictions in Central Europe
}

\author{
Franz Hanschmidt ${ }^{1}$ (D) - Anette Kersting ${ }^{1}$ \\ Received: 15 December 2020 / Accepted: 8 June 2021 \\ (C) The Author(s) 2021
}

\begin{abstract}
Aim Non-pharmaceutical interventions such as lockdowns have played a critical role in preventing the spread of the Covid-19 pandemic, but may increase psychological burden. This study sought to examine emotions reflected in social media discourse following the introduction of social contact restrictions in Central Europe.

Subjects and methods German-language Twitter posts containing '\#corona' and '\#covid-19' were collected between 2020/03/ $18-2020 / 04 / 24$. A total of 79,760 tweets were included in the final analysis. Rates of expressions of positive emotion, anxiety, sadness and anger were compared over time. Bi-term topic models were applied to extract topics of discussion and examine association with emotions.

Results Rates of anxiety, sadness and positive emotion decreased in the period following the introduction of social contact restrictions. A total of 16 topics were associated with emotions, which related to four general themes: social contact restrictions, life during lockdown, infection-related issues, and impact of the pandemic on public and private life. Several unique patterns of association between topics and emotions emerged.

Conclusion Results suggest decreasing polarity of emotions among the public following the introduction of social contact restrictions. Monitoring of social media activity may prove beneficial for an adaptive understanding of changing public concerns during the Covid-19 pandemic.
\end{abstract}

Keywords Natural language processing $\cdot$ Social media $\cdot$ Covid-19 $\cdot$ Anxiety $\cdot$ Emotions $\cdot$ Topic models

\section{Introduction}

After a period of rapid global spread, the World Health Organization (WHO) declared the coronavirus disease 2019 (Covid-2019) outbreak a global pandemic on 11 March 2020 (World Health Organization 2020). The first cases were observed in China in December 2019, and Covid-19 had infected 9,457,902 people worldwide by May 2020, causing an estimated 482,247 deaths (John Hopkins University 2020). The pandemic has put serious strain on healthcare systems given the high infection and transmission rates, the lack of efficient treatment options and the clinical severity of Covid-19 (Lipsitch et al. 2020). To prevent transmissions, several

Franz Hanschmidt

franz.hanschmidt@medizin.uni-leipzig.de

1 Department of Psychosomatic Medicine, University of Leipzig, Semmelweisstraße 10, 04103 Leipzig, Germany countries implemented a range of non-pharmaceutical interventions aiming at restricting social contacts, such as social distancing rules or lockdowns (Hsiang et al. 2020; Cheng et al. 2020). Countries in Central Europe (e.g. Germany, Austria, Switzerland) introduced comprehensive restrictions over a short period from the mid to end of March 2020, which largely prohibited social contacts, forced people to stay at home and led to nation-wide shutdowns of educational institutions and the public business sector (Hale et al. 2020). The psychological and emotional correlates of such comprehensive restrictions of social contact remain largely unexplored.

Adverse emotions experienced in response to a pandemic have been associated with increased psychological burden, unhealthy behaviours, and biased risk perception (Asmundson and Taylor 2020; Lin et al. 2020; Saltzman et al. 2020). Thus, understanding the emotional implication of the Covid-19 pandemic for the public is important for tailoring public health messages and service provision to people's needs. Anxiety has been identified as a central emotional response to the high risk of infection and the uncertainty related to the unpreceded circumstances 
during the Covid-19 pandemic. Several studies suggest that rates of anxiety, depression and stress are elevated in populations affected by Covid-19 (Luo et al. 2020). In a German survey, $60 \%$ and $74 \%$ of respondents reported being anxious and worried because of Covid-19 at the time the restrictions of social contact were announced (Betsch et al. 2020). Efforts aimed at limiting the spread of Covid-19, such as lockdowns and quarantine, often severely restrict people's capacities to access social and economic resources, which may result in anger and frustration (Brooks et al. 2020; de Las Heras-Pedrosa et al. 2020). Other study results indicate that positive emotions may emerge from increased feelings of support, e.g. from friends and family (Zhang and Ma 2020).

Information available on social media platforms such as Twitter constitute an important resource for monitoring emotional responses at different stages of the pandemic. A number of studies have analysed large bodies of Twitter posts ('tweets') to advance knowledge regarding public opinion, experiences of stigma or emotions related to Covid-19 (Budhwani and Sun 2020; Jimenez-Sotomayor et al. 2020; Rufai and Bunce 2020; Han et al. 2020). Findings of a study of tweets from English-language users suggests that common topics discussed on Twitter in the earlier phase of the pandemic include the origin of the virus, its socio-economic impact and risk of infection (Abd-Alrazaq et al. 2020). Most of the topics were characterized by positive emotions. In another analysis of English-language tweets, Lwin et al. found that emotions reflected in narratives on Twitter were dominated by fear related to disease spread in the beginning of the pandemic, and shifted to anger associated with social isolation as the pandemic progressed (Lwin et al. 2020). Language indicative of sadness was used in tweets related to loss of loved ones due to a Covid-19 infection, while positive emotion were expressed in tweets associated with gratitude, hope and resilience (Lwin et al. 2020).

These studies highlight the potential of using social media data to discover changing emotions and concerns of the public over the course of the Covid-19 pandemic. However, many available studies have analysed tweets posted by twitter users globally, representing a heterogeneous population with regard to exposure to infection risk and public health efforts to control the spread of the disease. Examining region-level social media discourse may allow for a more nuanced assessment of psychological and emotional responses of the public at different stages of the pandemic. A study that compared social media posts originating from regions of China and Italy before and after the lockdown found different patterns of languageuse reflecting different emotional responses ( $\mathrm{Su}$ et al. 2020). Anxiety appeared to decrease in Italy following the introduction of social contact restrictions, whereas negative emotions remained unchanged in China ( $\mathrm{Su}$ et al. 2020).

Several countries in Central Europe such as Germany, Austria and Switzerland simultaneously introduced comparable social contact restrictions over a short period from the mid to end of March 2020 (Hale et al. 2020). Public responses to these measures can be readily identified in social networks such as Twitter by focusing on German language use, which is used only in a confined geographical area in Central Europe covering mainly the populations of Germany, Austria and Switzerland (Eberhard et al. 2019). Thus, the aim of this study was to examine trends and topics associated with emotions reflected in German Covid-19related discourse on Twitter following the introduction of social contact restrictions in countries of German-speaking Central Europe. Results can be instructive for a more effective coordination of policy and health system response to the psychological outcomes of the Covid-19 pandemic.

\section{Methods}

\section{Data collection and cleaning}

Twitter's standard search API, which searches against a sample of tweets published in the past 7 days, was used for data collection. In a series of consecutive searches, Germanlanguage tweets that (a) contained the terms '\#corona', '\#coronavirus', '\#covid19' or '\#covid'; and (b) were published between 2020/03/18 and 2020/04/24 were collected. Usertags and geo-location of tweets were inspected to determine region of tweet origin.

Only tweets containing a self-reference (i.e. 'I', 'my', 'mine', 'me') were selected for further analysis to increase the probability of capturing expressions of individual emotions. Tweets were prepared for analyses in several steps: (1) Duplicates were removed in a two-stage process. First, duplicates were identified by inspecting the 'is_retweet' label provided by Twitter for each tweet. Second, as some retweets may not have been correctly labelled for technical reasons, the cosine similarity of tweets was additionally calculated to identify duplicate tweets; (2) The position-of-speech of words within tweets was determined; (3) Basic cleaning of tweets was conducted by removing URLs, usernames and converting all characters to lower case.

Data collected in this study were made publicly available by Twitter users, and were thus treated as data within the public domain (Stevens et al. 2015). User anonymity was ensured by presenting data in aggregated form only. Therefore, no further ethical approval was deemed necessary for this study. Data usage and processing in this study adhered to Twitter's Terms of Service and Developer's Agreement and Policy.

\section{Materials}

The German version of Linguistic Inquiry and Word Count (LIWC) dictionary was used to categorize words within tweets 
into four emotional categories based on previous research: positive emotion, anger, anxiety and sadness (Meier et al. 2019; Pennebaker et al. 2015; Lwin et al. 2020; Brooks et al. 2020; Luo et al. 2020). The LIWC dictionary has been specifically developed to capture an individual's psychological states as reflected in language use. It contains selected words which are organized into a set of psychological categories (e.g. positive emotions, anxiety). For a given document, the rate of word counts in the respective LIWC category to the total number of words $(\%)$ is calculated, with higher rates reflecting more pronounced emotion. Reliability of the German version of the LIWC has been demonstrated and meaningful associations with related psychological constructs in a number of studies indicate validity (Meier et al. 2019).

\section{Data analysis}

Sample characteristics were summarized using descriptive statistics (median, mean [M] and standard deviation [SD]).

Hashtags were removed before calculating rates of emotions as they are not a regular part of general language syntax and may bias word counts. To estimate changes in prevalence of emotions over times, tweets published on the same day were aggregated into a single document and rates of emotions were calculated. Time trends were modelled using logistic regression with day as independent and daily rate of emotion as the dependent variable.

In order to determine associations between emotions and tweet content, bi-term topic models were used to discover clusters of tweets with related content (Yan et al. 2013). A bi-term model (BTM) is based on the underlying assumption that word co-occurrences (i.e. bi-terms) within a set of documents (e.g. tweets) are generated by a mixture of probability distributions of unobserved topics (Yan et al. 2013). BTMs are especially suited to extract topics from short texts with sparse word co-occurrences like tweets (Yan et al. 2013). During the modelling process, words are probabilistically assigned to topics and these topic-word distributions allow for qualitative interpretation of the content of topics.

Topic models based on nouns-only have been shown to produce results which are more interpretable (Martin and Johnson 2015). Thus, only nouns, proper nouns and hashtags that (a) occurred in at least ten tweets; and (b) consisted of at least three characters were included in the topic modelling process. Additionally, we inspected the 100 most frequent words of this reduced corpus. We removed or merged terms that were judged to carry poor discriminative meaning and would thus occur in many topics (see S1 for sample flowchart). To guide decisions on the number of topics to extract, we calculated semantic coherence and exclusivity as metrics of topic quality as proposed in Roberts et al. (2019). Semantic coherence measures how well words assigned to a topic reflect the empirical co-occurrence of words within a set of documents (e.g. tweets) (Mimno et al. 2011). Exclusivity is based on a variant of the FREX metric (Bischof and Airoldi 2012), which assigns higher scores to topics containing words that are both frequent and exclusive to a given topic. We used formulas and code as provided by Roberts et al. (2019).

We ran a series of models with k-topic $(\mathrm{k}=$ $10,20,30,40,50,60,70,80,90,100)$ and selected the final model based on assessment of semantic coherence and exclusivity. Parameters estimated by the final model were used to assign each tweet its most likely topic. Associations between each topic and rates of emotions were calculated using logistic regressions with topic as dependent variable and rates of emotion as independent variables. Only topics showing a positive association with any emotion were retained. Finally, topics were labelled and interpreted by inspecting the topic-word distributions returned by the model. Two metrics were used to identify top words associated with each topic: probability and FREX. Probability is the statistical probability for a word to belong to a given topic, whereas the FREX metric weights the probability of words by their exclusivity for a given topic. Words which are both probable and exclusive score higher on the FREX metric (Roberts et al. 2019). Additionally, we inspected most likely tweets associated with each topic.

All data analysis was conducted using R (R Core Team 2019). Results with a $p$ value $<.05$ or a confidence interval that did not contain the null hypothesis were considered significant.

\section{Results}

\section{Sample characteristics}

Sample characteristics are displayed in Table 1. A total of 608,737 tweets were collected (no data collected on 202004-17). After removing duplicates and selecting tweets with

Table 1 Sample characteristics

\begin{tabular}{ll}
\hline Characteristic & Statistic \\
\hline Sampling period & $2020 / 03 / 18-2020 / 04 / 24$ \\
Number of tweets & 79270 \\
Mean (SD) number of tweets per day & $2156(\mathrm{SD}=914)$ \\
Number of unique users & 37,020 \\
Mean (SD) number of tweets by single users & $2.15(\mathrm{SD}=3.88)$ \\
User country of origin (n[\%]) & \\
Germany & $2590(3.25)$ \\
Switzerland & $185(0.23)$ \\
Austria & $173(0.22)$ \\
Other & $86(0.11)$ \\
Missing & $76726(96.2)$ \\
\hline
\end{tabular}


self-reference, 79,760 tweets were included in the analysis (see S1 for sample flowchart). The mean number of tweets posted per day was $\mathrm{M}=2156(\mathrm{SD}=914)$. Tweets were posted by 37,020 unique users with the mean number of tweets posted by a single user being $\mathrm{M}=2.15(\mathrm{SD}=3.88)$. Information on user-tagged country of origin of tweets was available for $3.8 \%(n=3034)$ of the sample. Of these, $97.2 \%$ were tagged with Germany $(85.4 \%, n=2590)$, Switzerland $(6.1 \%, n=185)$ or Austria $(5.7 \%, n=173)$ as the country of origin. Geo-location was enabled for $0.2 \%$ of all tweets only.

\section{Rates of emotions}

Figure 1 shows the rates of different emotions by day and the fitted trend lines. Time was significantly associated with decreasing rates of positive emotion $(b=-0.003, p<.001)$, anxiety $(b=-0.005, p<.001)$ and sadness $(b=-0.001, p=.040)$. Relative changes were largest for anxiety, which decreased by $18.2 \%$ (positive emotion $-9.4 \%$, sadness $-5.4 \%$, anger $3.5 \%$ ).

\section{Topic labels and associations with topics}

Inspection of semantic coherence and exclusivity values suggested that a topic model with $\mathrm{k}=30$ topics provided an adequate fit to the data (see S2). Rates of emotion were significantly increased in a total of 16 topics (sees Tables 2, 3 and S3 for an overview of topics). These topics were labelled based on the 15 top words identified by the probability and FREX metric. For example, the topic characterized by the words 'measures' and 'government' (probability metric) and the words 'fundamental rights' and 'citizen' (FREX metric) was subsequently labelled 'Political measures and implications for basic rights' (see Table 2). The labelled topics could be categorized into four broader themes (see Table 3).

1) Measures to prevent the spread of Covid-19: Topics in this theme included tweets relating to the impact of political measures to prevent disease spread (e.g. lockdown) on basic rights, social contact restrictions and compliance with these measures, the opening and closing of schools and communication and actions of political leaders.

2) Life during lockdown: Topics in this theme included tweets associated with caring for loved ones, homeoffice and leisure at home, information and digital technologies as well as environment and nature.

3) Infection-related issues: Topics in this theme were generated by tweets covering symptoms, testing and quarantine related to Covid-19, infection risk as well as gratitude for healthcare workers.

4) Impact of pandemic on public and private life: One topic in this theme comprised tweets related to a relatively broad discussions about the impact of the pandemic on the economy and society in conjunction with other global crises (e.g. climate change). Other topics related to panic

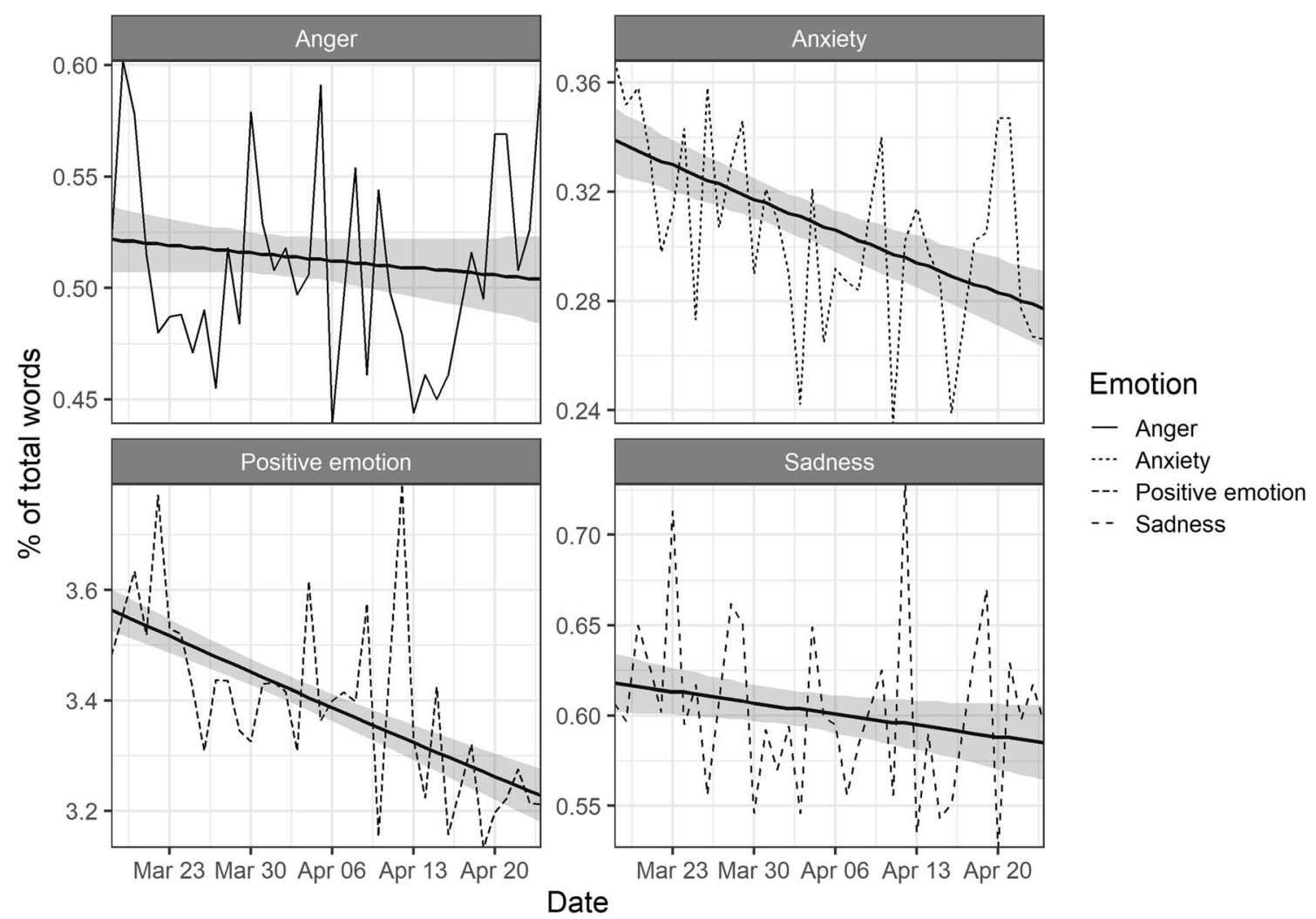

Fig. 1 Rates of emotions in Covid-19 related tweets by day. Trends lines and 95\% confidence interval fitted with logistic regressions 
Table 2 Words associated with topics

\begin{tabular}{|c|c|c|}
\hline Topic label & $\begin{array}{l}\text { Topic } \\
\%^{\mathrm{a}}\end{array}$ & Probability metric $^{\mathrm{b}}$ \\
\hline $\begin{array}{l}\text { Political measures and } \\
\text { implications for } \\
\text { basic rights }\end{array}$ & 23.9 & $\begin{array}{l}\text { measures, government, germany, question, crisis, \#merkel, } \\
\text { \#stayathome, economy, politics, opinion, country, population, } \\
\text { politician, fear, citizen }\end{array}$ \\
\hline $\begin{array}{l}\text { Social contact } \\
\text { restrictions and } \\
\text { compliance }\end{array}$ & 9.1 & $\begin{array}{l}\text { \#stayathome, distance, \#curfew, city, \#berlin, police, children, } \\
\text { curfew, berlin, groups, work, home, germany, \#contact ban, } \\
\text { street }\end{array}$ \\
\hline $\begin{array}{l}\text { Closing and opening } \\
\text { of schools }\end{array}$ & 1.8 & $\begin{array}{l}\text { school, schools, \#laschet, \#school opening, pupils, \#nrw, \#final } \\
\text { exams, \#school, children, \#schools, parents, teachers, } \\
\text { \#schoolboycottnrw, \#school boycott ger, \#loosening }\end{array}$ \\
\hline
\end{tabular}

FREX metric ${ }^{c}$

Political leaders

Caring for loved ones 1

Homeoffice and

leisure

Information and $\quad 4.5$ digital technologies

Environment and
nature

Symptoms, testing and quarantine

Infection risk

Gratitude for healthcare workers

\#stayathome, air, world, sun, nature, weather, \#ostern, rest, balcony, distance, \#distancing, garden, \#socialdistancing, crisis, dog

test, quarantine, contact, symptoms, doctor, fever, patients, cough, tests, question, hospital, \#stayathome, health authority, home, risk group

anxiety, patients, hospital, death, risk group, home, relatives, mother, pre-existing conditions, worry, italy, thoughts, family, deaths, situation

hanks, doctors, \#care, patients, colleagues, \#stayathome, crisis, personnel, nurses, staff, coimmitment, masks, staff, care

Economic and societal crisis

crisis, world, fear, economy, society, \#stayathome, solidarity, germany, children, pandemic, country, politician, opinion, situation, future

Panic buying

loo paper, \#loo paper, toilet paper, \#toilet paper, flour, \#hamster purchases, noodles, pack, \#stayathome, supermarket, \#hamster purchases, packs, rolls, yeast, bread

Conspiracy theories and misinformation

\#trump, trump, usa, \#usa, boris, johnson, \#johnson, \#qanon, new, york, donald, world, \#who, deepstatevirus, president

Religion

Other affected regions 2 and populations

easter, \#easter, \#afd, church, \#noafd, churches, \#ramadan, jesus, \#church, \#stayathome, family, hope, love, power, afd

germany, italy, china, europe, \#italia, country, \#eu, countries, world, usa, solidarity, \#europe, \#germany, \#china, aid \#merkel, merkel, \#cdu, \#spd, \#söder, \#laschet, angela, \#csu, krise, \#fdp, \#spahn, chancellor, söder, speeches, \#afd

children, parents, child, family, children, home, \#stayathome, mother, grandmother, daughter, school, father, friends, kita, mum

\#stayathome, \#homeoffice, home quarantine, thank you, work, home office, children, world, evening, family, child, head, toilet paper, \#quarantine

questions, \#homeoffice, crisis, \#stayathome, article, app, \#digitalization, thank you, contribution, work, tips, answer, infos, colleagues, company

fundamental rights, citizen, freedom, debate, restriction, relaxation, measures, restriction, citizen, democracy, containment, federal government, strategy, criticism, federal council

groups, parks, streets, police, city, park, street, bike, flat, pensioner, curfew, idiots, flats, windows, party

\#final exams, \#school openings, pupils, \#school opening, \#school boycotts ger, \#school, lessons, exams, \#school boycott nrw, final exams, \#gebauer, \#average exams, high-school graduate, \#schools, \#school boycotts

angela, \#cdu, \#fdp, \#csu, federal chancellor, \#spd, merkel, chancellor, söder, speech, \#merkel, speech, cdu, merkels, prime ministers

kita, grandpa, parents, playground, \#kita, grandma, child, grandparents, children, grandchildren, mum, dad, daughter, emergency care

home office, office, \#homeoffice, books, couch, film, netflix, living room, isolation, sofa, internet, flat, coffee, cat, bed

\#data protection, \#digitisation, webinar, challenges, \#newwork, digitisation, hackathon, apps, blog, tips, app, \#hackathon, \#app, google, teams

cats, nature, \#notjustsad, sea, snow, cars, \#rastatt, forest, \#orchestra, dog, cycling, birds, \#beethoven, \#bathing, aeroplanes

fever, cough, test, general practitioner, health office, symptoms, smear test, symptoms, result, contact, call, doctor, quarantine, risk region

respiration, preexisting conditions, relatives, course, age, condolence, smoker, lung, sick, death, intensive, fear, anxiety, risk groups, cancer

nurse, \#nursing, \#nursing crisis, \#nursing, \#nursing, \#nursing, heroes, \#nursing, running, nurses, working conditions, payment, applause, care, \#hospital, \#system relevant

\#climate crisis, egoism, freedom, society, \#fridaysforfuture, economy, climate, climate change, planet, chance, \#climate change, \#fff, future, humanity, thinking

flour, pasta, loo paper, \#hamster purchases, \#hamster purchases, yeast, \#toilet paper gate, packs, \#flour, milk, toilet paper, pack, rolls, \#loo paper, \#toilet paper

\#deepstatevirus, \#johnson, \#deepstateexposed, \#qanon, boris, trump, donald, \#trump, \#deepfake, johnson, \#draintheswamp, \#deepstatetakedown, \#satanicelite, \#trumpvirus, american jesus, \#ramadan, churches, christians, church, god, \#prohibit afd now, prayer, \#fckafd, nazis, mosques, \#belief, \#church, muslim, \#noafd

europe, greece, \#lesbos, russia, \#eu, \#leavenoonebehind, countries, iran, \#moria, 
Table 2 (continued)

\begin{tabular}{lll}
\hline Topic label & $\begin{array}{l}\text { Topic } \\
\%^{\mathrm{a}}\end{array}$ & Probability metric $^{\mathrm{b}}$ \\
& $\begin{array}{l}\text { europe, \#spain, \#refugees, \#greece, \#europe, } \\
\text { cuba }\end{array}$
\end{tabular}

Top 15 words of topics that showed significant associations with an emotion; ${ }^{a}$ Proportion of tweets assigned to topic; ${ }^{b}$ Most probable words per topic; ${ }^{\mathrm{c}}$ Words with highest FREX scores per topics, i.e. most probable words weighted by their exclusivity for a given topic

buying, conspiracy theories and (mis)information, religion as well as the pandemic situation in other world regions and populations, e.g. refugee camps.

Topics relating to the theme 'Measures to prevent spread of Covid-19' were mostly related to anger and anxiety, although discussions of political leaders were associated with positive emotions. The majority of topics belonging to the theme 'life during lockdown' were associated with positive emotions. Only tweets belonging to the topic of caring for loved ones were associated with anxiety and sadness. Topics included in the theme 'infection' were mostly associated with anxiety and sadness, except for the topic gratitude for healthcare workers, which was associated with positive emotions. Most topics covered by the theme 'impact of pandemic on public and private life' were associated with anxiety, anger or sadness.
Topics most strongly associated with either anger, anxiety, sadness or positive emotion comprised $18.6 \%, 29.7 \%, 5.3 \%$ and $26.5 \%$ of all tweets, respectively. The remaining $19.9 \%$ of tweets were assigned to topics not significantly related to any emotion.

\section{Discussion}

Non-pharmaceutical interventions such as social contact restrictions and lockdowns have proven effective in slowing the spread of Covid-19; however, little is known about the psychological responses of the public to the pandemic and efforts to control it (Hsiang et al. 2020). We found that rates of anxiety, sadness and positive emotion in Twitter statements decreased over a 1-month period following the introduction of social contact restrictions in German-speaking countries of

Table 3 Topics and associations with emotions

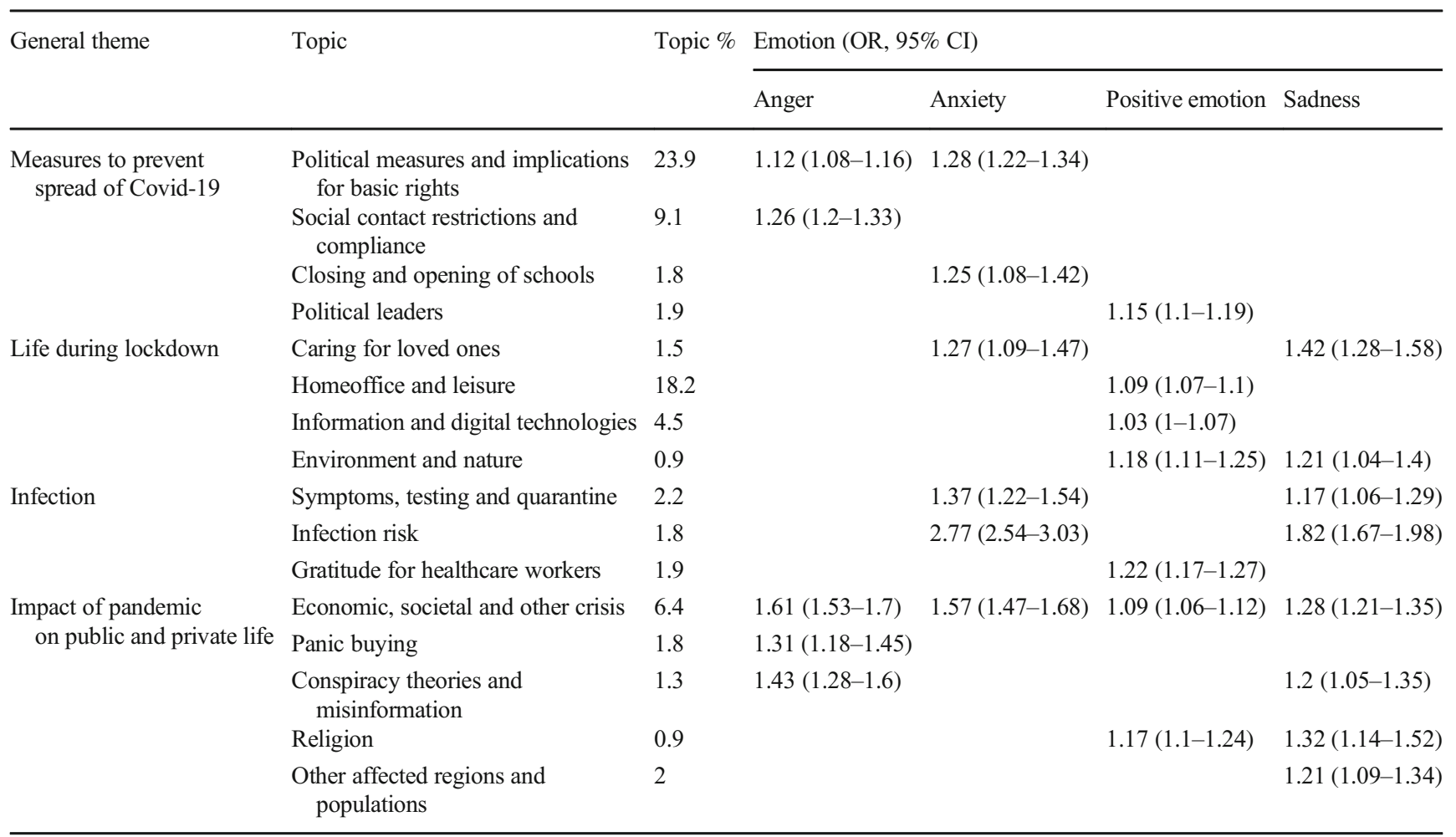


Central Europe, suggesting reduced polarity of emotional expressions in tweets. Several topics emerged in Twitter discourse that were related to implications of the Covid-19 pandemic in general and to the introduction of social contact restrictions specifically.

Cautious interpretation of these results is warranted, as an individual's use of words may not precisely reflect underlying psychological states. While several findings show that measures of subjective well-being or mental health are associated with differences in language use, other studies did not find a relationship between psychological measures and language use (Meier et al. 2019; Sonnenschein et al. 2018). Thus, results of linguistic analyses such as this study should be interpreted in conjunction with other indicators of public well-being. In this study, rates of words related to anxiety showed the largest decrease over time. This result may suggest a possible link between governmental efforts to control the pandemic and decreasing anxiety among the public (Luo et al. 2020). In Germany, for example, public approval of social contact restrictions was high at the time of their introduction and Twitter statements concerning political leaders were associated with more positive emotion in this study (Teufel et al. 2020). However, no causal link between governmental interventions and rates of emotions in Twitter statements can be established due to the observational design of this study and the lack of a control group.

It is also possible that decreasing rates of anxiety-related words in Twitter statements reflect a habituation or emotional numbness to pandemic stressors. Topics related to anxiety were most prevalent in this sample. These results corroborate other research showing heightened levels of anxiety in populations affected by Covid-19 (Wang et al. 2020). Congruent with findings from other studies, sources of anxiety and sadness were mainly related to the impact of the pandemic on family and social life, education, as well as infection, pointing to an need to address these public concerns (Mertens et al. 2020; AbdAlrazaq et al. 2020). With regard to social contact restrictions, anxiety was associated with topics discussing potential negative impacts of both implementation (e.g. with regard to basic rights) and relaxation of social contact restrictions (e.g. re-opening of schools), which suggests nuanced public risk perceptions.

Personal statements expressing positive emotions declined steadily following the introduction of social contact restrictions. Psychological strain resulting from enduring social isolation in addition to the absence of directly observable effects of prevention efforts (e.g. avoiding increasing rather than reducing case-fatality rates) may have inhibited positive emotions. However, topics relating to positive emotions comprised approximately one-quarter of all tweets, indicating that social networks constitute an important source for people to share positive messages of coping with staying at home or solidarity (e.g. with healthcare workers).

Expressions of anger did not change in tweets posted after the introduction of social contact restrictions. Anger was related to social contact restrictions and compliance with these measures, but it remains unclear whether Twitter users expressed anger about having to comply with restrictions or about other people not complying. Anger was also related to statements surrounding the credibility of Covid-19-related information. Misinformation on social media has been identified as a major barrier for public health efforts to prevent disease spread, promoting unhealthy behaviour and erroneous practices that can ultimately harm physical and mental health (Tasnim et al. 2020). The association with anger observed in this study may indicate increasing public awareness and rejection of misinformation, but also highlights the need for concerted efforts strengthening the position of authentic sources of information.

\section{Limitations}

Several limitations to this study need to be considered. The target population of this study were Twitter users living in a country in German-speaking Central Europe, but we were not able to determine the exact origin of the majority of tweets. However, user-tagged country of origin indicated that the vast majority of tweets originated from users in Germany, Switzerland or Austria. The following issues specifically limit the generalizability of results: First, we used one of Twitter's free data access point for which Twitter does not provide all tweets matching a certain search query but samples a collection of tweets with undisclosed underlying sampling scheme. Second, we used a hashtag-based search to identify relevant tweets, seeking to increase the relevance of tweets obtained via Twitter's data access point. However, samples of tweets collected by hashtag-based searches may not be representative of discourse related to a specific topic (Bruns and Stieglitz 2014). Third, compared to the general population, Twitter users have been shown to be younger, higher educated and more politically liberal (Mellon and Prosser 2017). Last, there was indication that the vast majority of the tweets were posted by German users, followed by users from Switzerland and Austria (97.2\% for the three countries combined), which limits the generalizability of results to other countries. Although the timing and stringency of social contact restrictions within Germany, Switzerland and Austria were largely comparable (Hale et al. 2020), different experiences within these populations may have also reduced generalizability of results across these countries.

Furthermore, the word count approach we used to estimate the prevalence of emotions in our sample did not allow identifying negations and other contextual shifters of word meanings (e.g. sarcasm). However, we calculated rates of emotions based on aggregated tweets only (i.e. at the overall or daily level), and thus single misclassifications are unlikely to bias overall results. Observed changes in rates of emotion in Twitter discourse may represent lagged effects of events other than the introduction of social contact restrictions. We were not able to collect data for 1 day in the study period. However, 
bias resulting from this minimal lack of data is likely to be negligible.

\section{Conclusion}

Polarity of emotions expressed by Twitter users decreased following the introduction of social contact restrictions in countries of German-speaking central Europe, mainly driven by decreases in anxiety. Findings further revealed nuanced emotional responses to different aspects of social contact restrictions and the pandemic in general. Providing the public with accessible rationales for both implementation and relaxation of social contact restrictions as well as reliable information on epidemiological and medical aspects of the virus may buffer negative emotions. Continuous monitoring of social media activity at a regional level can contribute to adaptive understanding and responses to changing public concerns over the course of the pandemic.

\section{Appendix}

\section{S1. Sample flowchart}

Fig. 2 Sample flowchart

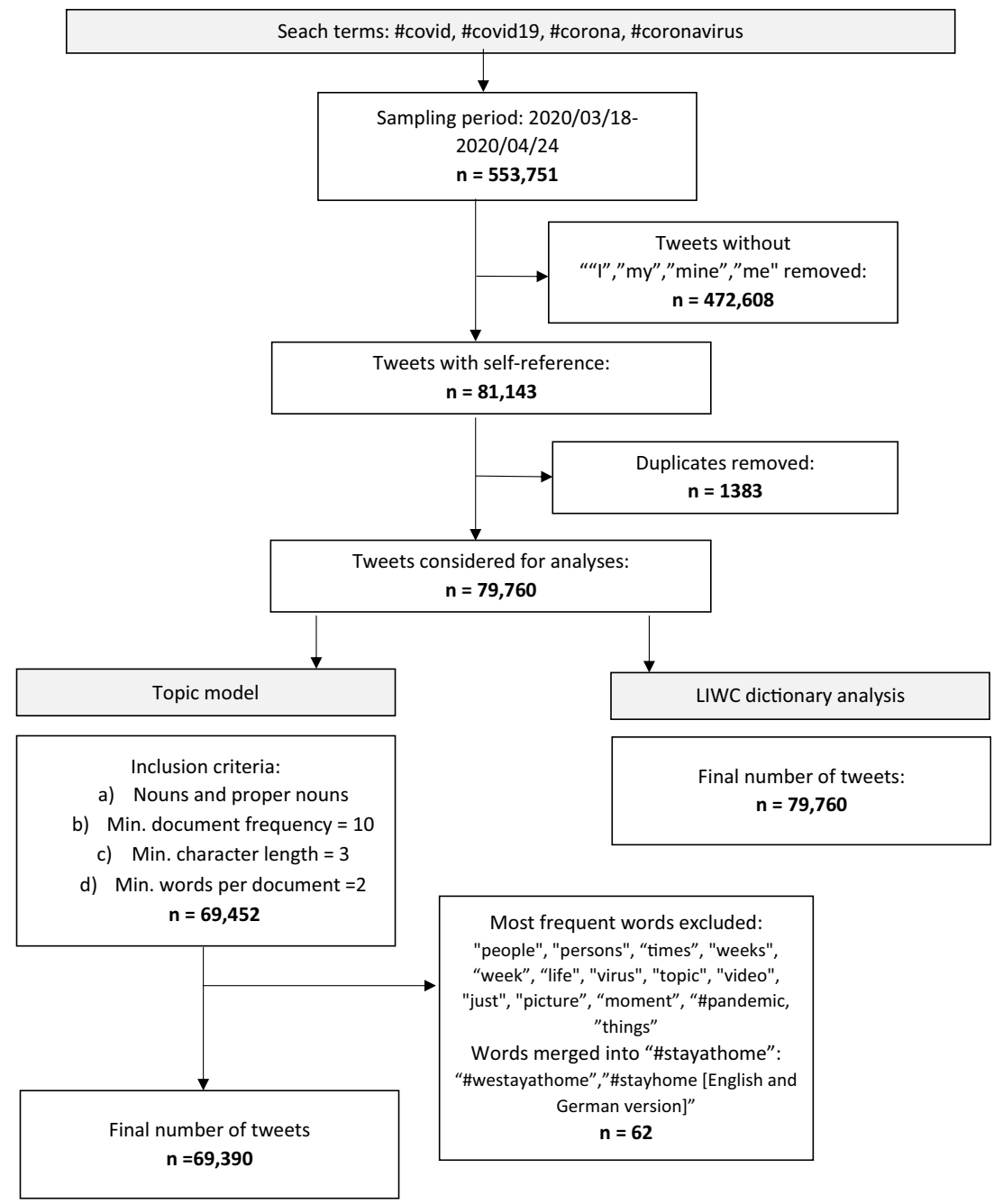




\section{S2. Model selection process}

Average exclusivity values showed the largest increases for the model with 30 topics, after which trends appeared to flatten out (see Fig. 3). Average semantic coherence was highest for the model with 30 topics. Thus, we chose the model with 40 topics for further analyses.

Fig. 3 Average exclusivity and semantic coherence models with k-topics

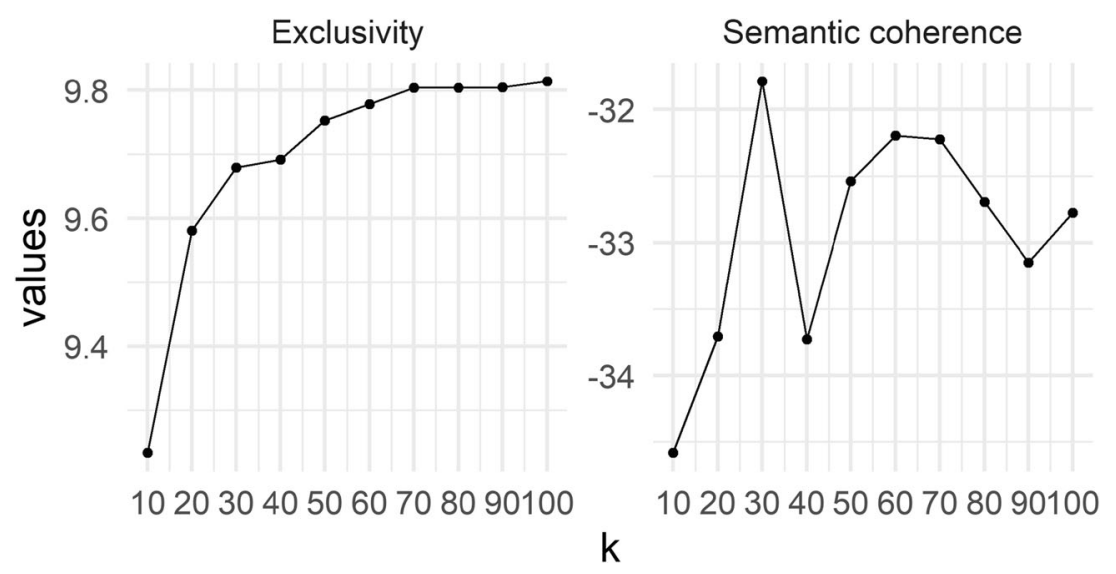

\section{S3. Topic labels, proportions and associated words}

\begin{tabular}{|c|c|c|c|c|c|c|}
\hline \multirow{2}{*}{$\begin{array}{l}\text { Topic } \\
\mathrm{Nr}\end{array}$} & \multirow[t]{2}{*}{ Topic label $^{\mathrm{a}}$} & \multirow[t]{2}{*}{$\%^{\mathrm{b}}$} & \multicolumn{2}{|l|}{ Topic words: German (original) } & \multicolumn{2}{|l|}{ Topic words: English } \\
\hline & & & Probability metric ${ }^{\mathrm{c}}$ & FREX metric $^{\mathrm{d}}$ & Probability metric ${ }^{c}$ & FREX metric $^{\mathrm{d}}$ \\
\hline 1 & $\begin{array}{l}\text { Caring for } \\
\text { loved ones }\end{array}$ & 1.5 & $\begin{array}{l}\text { kinder, eltern, kind, familie, } \\
\text { kindern, hause, } \\
\text { \#stayathome, mutter, oma, } \\
\text { tochter, schule, vater, } \\
\text { freunde, kita, mama }\end{array}$ & $\begin{array}{l}\text { kita, opa, eltern, spielplatz, } \\
\text { \#kita, oma, kind, kindern, } \\
\text { großeltern, kinder, enkel, } \\
\text { mama, papa, tochter, } \\
\text { notbetreuung }\end{array}$ & $\begin{array}{l}\text { children, parents, child, } \\
\text { family, children, home, } \\
\text { \#stayathome, mother, } \\
\text { grandmother, daughter, } \\
\text { school, father, friends, } \\
\text { kita, mum }\end{array}$ & $\begin{array}{l}\text { kita, grandpa, parents, } \\
\text { playground, \#kita, } \\
\text { grandma, child, } \\
\text { grandparents, children, } \\
\text { grandchildren, mum, dad, } \\
\text { daughter, emergency care }\end{array}$ \\
\hline 2 & $\begin{array}{l}\text { Closing and } \\
\text { opening of } \\
\text { schools }\end{array}$ & 1.8 & $\begin{array}{l}\text { schule, schulen, \#laschet, } \\
\text { \#schuloeffnung, schüler, } \\
\text { \#nrw, \#abitur, \#schule, } \\
\text { kinder, \#schulen, eltern, } \\
\text { lehrer, \#schulboykottnrw, } \\
\text { \#schulboykottde, } \\
\text { \#lockerungen }\end{array}$ & $\begin{array}{l}\text { \#abitur, \#schuloeffnung, } \\
\text { schüler, } \\
\text { \#schuloeffnungen, } \\
\text { \#schulboykottde, \#schule, } \\
\text { unterricht, prüfungen, } \\
\text { \#schulboykottnrw, abitur, } \\
\text { \#gebauer, } \\
\text { \#durchschnittsabitur, } \\
\text { abiturienten, \#schulen, } \\
\text { \#schulboykott }\end{array}$ & $\begin{array}{l}\text { school, schools, \#laschet, } \\
\text { \#school opening, } \\
\text { pupils, \#nrw, \#final } \\
\text { exams, \#school, } \\
\text { children, \#schools, } \\
\text { parents, teachers, } \\
\text { \#schoolboycottnrw, } \\
\text { \#school boycott ger, } \\
\text { \#loosening }\end{array}$ & $\begin{array}{l}\text { \#final exams, \#school } \\
\text { openings, pupils, \#school } \\
\text { opening, \#school boycotts } \\
\text { ger, \#school, lessons, } \\
\text { exams, \#school boycott } \\
\text { nrw, final exams, } \\
\text { \#gebauer, \#average } \\
\text { exams, high-school } \\
\text { graduate, \#schools, } \\
\text { \#school boycotts }\end{array}$ \\
\hline 3 & $\begin{array}{l}\text { Social contact } \\
\text { restrictions } \\
\text { and } \\
\text { compliance }\end{array}$ & 9.1 & $\begin{array}{l}\text { \#stayathome, abstand, } \\
\text { \#ausgangssperre, stadt, } \\
\text { \#berlin, polizei, kinder, } \\
\text { ausgangssperre, berlin, } \\
\text { gruppen, arbeit, hause, } \\
\text { deutschland, } \\
\text { \#kontaktverbot, straße }\end{array}$ & $\begin{array}{l}\text { gruppen, parks, straßen, } \\
\text { polizei, stadt, park, straße, } \\
\text { rad, wohnung, rentner, } \\
\text { ausgangssperre, idioten, } \\
\text { wohnungen, fenster, party }\end{array}$ & $\begin{array}{l}\text { \#stayathome, distance, } \\
\text { \#curfew, city, \#berlin, } \\
\text { police, children, } \\
\text { curfew, berlin, groups, } \\
\text { work, home, germany, } \\
\text { \#contact ban, street }\end{array}$ & $\begin{array}{l}\text { groups, parks, streets, police, } \\
\text { city, park, street, bike, } \\
\text { appartment, pensioner, } \\
\text { curfew, idiots, flats, } \\
\text { windows, party }\end{array}$ \\
\hline 4 & $\begin{array}{l}\text { Conspiracy } \\
\text { theories and }\end{array}$ & 1.3 & $\begin{array}{l}\text { \#trump, trump, usa, \#usa, } \\
\text { boris, johnson, \#johnson, }\end{array}$ & $\begin{array}{l}\text { \#deepstatevirus, \#johnson, } \\
\text { \#deepstateexposed, }\end{array}$ & $\begin{array}{l}\text { \#trump, trump, usa, \#usa, } \\
\text { boris, johnson, }\end{array}$ & $\begin{array}{l}\text { \#deepstatevirus, \#johnson, } \\
\text { \#deepstateexposed, }\end{array}$ \\
\hline
\end{tabular}


misinformation

Environment and nature

0.9 \#stayathome, luft, welt, sonne, natur, wetter, \#ostern, ruhe, balkon, abstand, \#abstandhalten, garten, \#socialdistancing, krise, hund

Economic, societal and other crisis

6.4 krise, welt, angst, wirtschaft, gesellschaft, \#stayathome, solidarität, deutschland, kinder, pandemie, land, politiker, meinung, situation, zukunft

Gratitude for healthcare workers regions and populations and leisure

\section{angst, patienten,}

krankenhaus, tod,

risikogruppe, hause angehörigen, mutter, vorerkrankungen, sorgen, italien, gedanken, familie, tote, situation

Information and digital technologies

\section{5}

fragen, \#homeoffice, krise, \#stayathome, artikel, app, \#digitalisierung, danke, beitrag, arbeit, tipps, antworten, infos, kollegen, unternehmen
Panic buying $\quad 1.8$ klopapier, \#klopapier, toilettenpapier, \#toilettenpapier, mehl, \#qanon, boris, trump, donald, \#trump, \#deepfake, johnson, \#draintheswamp, \#deepstatetakedown, \#satanicelite, \#trumpvirus, amerikaner

katzen, natur, \#notjustsad, meer, schnee, autos, \#rastatt, wald, \#orchester, hund, radfahren, vögel, \#beethoven, \#baden, flugzeuge

\#klimakrise, egoismus, freiheit, gesellschaft, \#fridaysforfuture, wirtschaft, klima, klimawandel, planeten, chance, \#klimawandel, \#fff, zukunft, menschheit, denk

pfleger, \#pflegenotstand, pflegekräfte, \#pflege, \#pflegekräfte, helden, \#pflegekraefte, laufen, krankenschwestern, arbeitsbedingungen, bezahlung, applaus, pflege, \#krankenhaus, \#systemrelevant

europa, griechenland, \#lesbos, russland, \#eu, \#leavenoonebehind, länder, iran, \#moria, europas, \#spanien, flüchtlinge, \#griechenland, \#europa, kuba

homeoffice, büro, \#homeoffice, bücher, couch, film, netflix, wohnzimmer, isolation, sofa, internet, wohnung, kaffee, katze, bett

beatmung, vorerkrankungen, a angehörigen, verlauf, alter, beileid, raucher, lunge, kranke, tod, intensiv, angst, ängste, risikogruppen, krebs

\#datenschutz, \#digitalisierung, webinar, herausforderungen, \#newwork, digitalisierung, hackathon, apps, blog, tipps, app, \#hackathon, \#app, google, teams

mehl, nudeln, klopapier, \#hamsterkaeufe, \#hamsterkäufe, hefe, \#johnson, \#qanon, new, york, donald, world, \#who, \#deepstatevirus, president

\#stayathome, air, world, sun, nature, weather, \#ostern, rest, balcony, distance, \#distancing, garden,

\#socialdistancing, crisis, dog

crisis, world, fear, economy, society, \#stayathome, solidarity, germany, children, pandemic, country, politician, opinion, situation, future

thanks, doctors, \#care, patients, colleagues, \#stayathome, crisis, personnel, nurses, staff, coimmitment, masks, staff, care

germany, italy, china, europe, \#italia, country, \#eu, countries, world, usa, solidarity, \#europe, \#germany, \#china, aid

\#stayathome,

\#homeoffice, home quarantine, thank you, work, home office, children, world, evening, family, child, head, toilet paper, \#quarantine

anxiety, patients, hospital death, risk group, home, relatives, mother, pre-existing conditions, worry, italy, thoughts, family, deaths, situation

questions, \#homeoffice, crisis, \#stayathome, article, app, \#digitalization, thank you, contribution, work, tips, answer, infos, colleagues, company

loo paper, \#loo paper, toilet paper, \#toilet paper, flour, \#hamster \#qanon, boris, trump, donald, \#trump, \#deepfake, johnson, \#draintheswamp, \#deepstatetakedown, \#satanicelite, \#trumpvirus, american

cats, nature, \#notjustsad, sea, snow, cars, \#rastatt, forest, \#orchestra, dog, cycling, birds, \#beethoven, \#bathing, aeroplanes

\#climate crisis, egoism, freedom, society, \#fridaysforfuture, economy, climate, climate change, planet, chance, \#climate change, \#fff, future, humanity, thinking

nurse, \#nursing, \#nursing crisis, \#nursing, \#nursing, \#nursing, heroes, \#nursing, running, nurses, working conditions, payment, applause, care, \#hospital, \#system relevant

europe, greece, \#lesbos, russia, \#eu, \#leavenoonebehind, countries, iran, \#moria, europe, \#spain, \#refugees, \#greece, \#europe, cuba

home office,office, \#homeoffice, books, couch, film, netflix, living room, isolation, sofa, internet, flat, coffee, cat, bed

respiration, preexisting conditions, relatives, course, age, condolence, smoker, lung, sick, death, intensive, fear, anxiety, risk groups, cancer

\#data protection, \#digitisation, webinar, challenges, \#newwork, digitisation, hackathon, apps, blog, tips, app, \#hackathon, \#app, google, teams

flour, pasta, loo paper, \#hamster purchases, \#hamster purchases, 
\#hamsterkaeufe, nudeln, packung, \#stayathome, supermarkt,

\#hamsterkäufe, packungen, rollen, hefe, brot leaders

\section{9} \#söder, \#laschet, angela, \#csu, krise, \#fdp, \#spahn, kanzlerin, söder, rede, \#afd

Political
measures
and
implications
for basic
rights

23.9 maßnahmen, regierung, deutschland, frage, krise, \#merkel, \#stayathome, wirtschaft, politik, meinung, land, bevölkerung, politiker, angst, bürger

9 ostern, \#ostern, \#afd, kirche, \#noafd, kirchen, \#ramadan, jesus, \#kirche, \#stayathome, familie, hoffnung, liebe, kraft, afd

2.8 zahlen, deutschland, zahl, tote, italien, fälle, daten, anzahl, tests, infizierten, toten, maßnahmen, todesfälle, \#deutschland, usa informationen, fragen, twitter, \#stayathome, youtube, artikel, nachrichten, facebook, situation, frage, \#fakenews, videos, beitrag impfstoff, \#drosten, experten, drosten, \#lanz, meinung, virologen, virologe, viren, studie, interview

$$
\text { \#flattenthecurve, hause, }
$$

\#klopapiergate, packungen, \#mehl, milch, toilettenpapier, packung, rollen, \#klopapier,

\#toilettenpapier

angela, \#cdu, \#fdp, \#csu, bundeskanzlerin, \#spd, merkel, kanzlerin, söder, rede, \#merkel, ansprache, cdu, merkels, ministerpräsidenten

grundrechte, freiheit, debatte, einschränkungen, lockerung, maßnahmen, einschränkung, massnahmen, bürger, demokratie, eindämmung, bundesregierung, strategie, kritik, bundesrat

jesus, \#ramadan, kirchen, christen, kirche, gottes, \#afdverbotjetzt, gebet, \#fckafd, nazis, moscheen, \#glaube, \#kirche, muslime, \#noafd

fieber, husten, test, hausarzt, gesundheitsamt, symptome, abstrich, symptomen, ergebnis, kontakt, anruf, arzt, ärztin, quarantäne, risikogebiet

firmen, \#soforthilfe, soforthilfe, kredite, antrag, \#kurzarbeit, freiberufler, hilfen, steuern, künstler, staat, kurzarbeit, \#bge, banken, gutscheine

zahl, einwohner, todesfälle, zahlen, anzahl, anstieg, neuinfektionen, fallzahlen, infizierten, tote, hopkins, vergleich, wachstum, infektionen, fälle

facebook, zdf,

berichterstattung, informationen, sender, verschwörungstheorien, youtube, fakten, vogt, account, journalismus, twitter, radio, sendung, qualität

prof., drosten, \#drosten, virologe, streeck, dr., impfstoff, \#wieler, wieler, bhakdi, impfung, experten, \#streeck, virologen, experte

\#stayathomechallenge, bleibt, purchases, noodles, pack, \#stayathome, supermarket, \#hamster purchases, packs, rolls, yeast, bread

\#merkel, merkel, \#cdu, \#spd, \#söder, \#laschet, angela, \#csu, krise, \#fdp, \#spahn, chancellor, söder, speeches, \#afd

measures, government, germany, question, crisis, \#merkel, \#stayathome, economy, politics, opinion, country, population, politician, fear, citizen

easter, \#easter, \#afd, church, \#noafd, churches, \#ramadan, jesus, \#church, \#stayathome, family, hope, love, power, afd

test, quarantine, contact, symptoms, doctor, fever, patients, cough, tests, question, hospital, \#stayathome, health authority, home, risk group

money, crisis, company, clients, euro, economy, short time, employee, company, short time work, help, state, question, employee, thank you, support

numbers, germany, number, dead, italy, cases, data, number, tests, infected, dead, measures, deaths, \#germany, usa

thanks, media, information, questions, twitter, \#stayathome, youtube, article, news, facebook, situation, question, \#fakenews, videos, contribution

dr., prof., \#rki, influenza, vaccine, \#drosten, expert, drosten \#lanz, opinion, virologist, virologist, virus, study, interview

\#stayathome, \#flattenthecurve, home yeast, \#toilet paper gate, packs, \#flour, milk, toilet paper, pack, rolls, \#loo paper, \#toilet paper

angela, \#cdu, \#fdp, \#csu, federal chancellor, \#spd, merkel, chancellor, söder, speech, \#merkel, speech, cdu, merkels, prime ministers

fundamental rights, citizen, freedom, debate, restriction, relaxation, measures, restriction, citizen, democracy, containment, federal government, strategy, criticism, federal council

jesus, \#ramadan, churches, christians, church, god, \#prohibit afd now, prayer, \#fckafd, nazis, mosques, \#belief, \#church, muslim, \#noafd

fever, cough, test, general practitioner, health office, symptoms, smear test, symptoms, result, contact, call, doctor, quarantine, risk region

companies, \#emergency aid, emergency aid, loans, application, \#short work, freelancer, help, taxes, state, short work, \#bge, banks, vouchers, artist

number, population, deaths, numbers, number, increase, increase, number, new infections, number of cases, infected, fatalities, hopkins, comparison, growth, infections, cases

facebook, zdf, broadcast, information, broadcaster, conspiracy theories, youtube, facts, vogt, account, journalism, twitter, radio, reporting, quality

prof., drosten, \#drosten, virologist, streeck, dr., vaccine, \#wieler, wieler, bhakdi, vaccination, experts, \#streeck, virologist, expert

\#stayathomechallenge, stay, \#stayhomesavelives, 
\#ausgangssperre, \#homeoffice,

\#socialdistancing,

\#bleibtgesund,

\#zuhausebleiben,

zuhause,

\#stayhomesavelives,

\#bleibzuhause, \#staysafe,

danke, \#ostern,

\#quarantaene

2 abstand, supermarkt, kasse,

kunden, hände,

mundschutz,

einkaufswagen, hand,

meter, maske,

handschuhe, laden,

gesicht, einkaufen, paket

1.8 masken, maske,

\#maskenpflicht,

mundschutz,

\#mundschutz, \#maskeauf,

\#masken, \#maske, nase,

pflicht, mund, tragen,

maskenpflicht, schutz,

\#schutzmasken

1.1 \#deutschland, \#stayathome, \#politik, \#wirtschaft,

\#gesundheit, \#krise,

\#virus, \#merkel, \#zdf,

\#gesellschaft,

\# exitstrategie, \#medien, \#maskenpflicht, \#lanz,

\#solidarität

1.1 april, mai, anfang, schulen,

mitte, \#stayathome, geschäfte, bayern, märz, urlaub, lockerungen, montag, \#lockdown, august, maßnahmen

0.7 \#stayathome, \#youtube, \#twitch, \#twitchde, \#gaming, \#streamer, spaß, \#livestream, \#live, \#letsplay, \#stream, \#streaming, \#video, \#twitchstreamer, kanal

0.6 \#bundesliga, \#kurz, fußball, \#dfl, \#ischgl, \#övp, \#tirol, \#fussball, \#geisterspiele, \#österreich, \#gruenen, österreich, \#kogler, \#tuerkisgruen, spieler

0.3 \#adidas, miete, \#deichmann, \# himmel, \#online, handy, beitrag, \#miete, adidas, \#letzebuerg, \#hundm, \#info, \#news, \#media, vermieter \#stayhomesavelives, \#wirbleibendaheim, \#staythefuckhome, \#wirschaffendas, \#bleibtgesund, \#zu, \#flattenthecurve, \#flattenthecuve, hausebleiben, universum, \#wirbleibenzu, \#staysafe, \#deutschlandmachtmusik

einkaufswagen, kasse, meter, schlange, wagen, unterschrift, eingang, kunde, mindestabstand, handschuhe, ware, stift, aldi, kunden, verkäuferin

\#maskeauf, tragen, \#mundschutzpflicht, pflicht, nähmaschine, \#mundschutzmasken, brille, \#maske, \#mundschutz, masken, maske, \#plauen, \#vogtland, \#faceshield, \#masken

\#wirtschaft, \#gesellschaft, \#gesundheit, \#freiheit, \#bürger, \#politik, \#exitstrategie, \#medien, \#wissenschaft, \#exit, \#börse, \#panik, \#menschen, \#zdf, \#krise

august, mitte, april, großveranstaltungen, restaurants, friseure, veranstaltungen, mai, juni, friseur, konzerte, oktoberfest, september, hotels, bars

\#streamer, \#twitchde, \#twitch, \#gaming, \#letsplay,

\#twitchstreamer, \#stream, \#twitchtv, \#livestream, \#rap, \#streaming, \#youtuber, \#live, \#supportsmallstreamers, \#germanmediart

\#fussball, \#dfl,

\#tuerkisgruen, \#bundesliga, \#kogler, \#geisterspiele, \#dfb, fußball, \#oevp, \#anschober, \#platter, \#tirol, geisterspiele, saison, fussball

\#letzebuerg, \#deichmann, \#adidas, \#hundm, adidas, spiegelreflexkamera, witterung, \#info, \#letzebuergesch, \#media, \#curfew, \#homeoffice, \#socialdistancing, \#stayhealthy, \#stay at home, \#stayhomesavelives, \#stay at home, \#staysafe, thank you, \#ostern, \#quarantine

distance, supermarket, cash desk, customers, hands, mouth protection, shopping cart, hand, meter, mask, gloves, load, face, shopping, package

masks, mask, \#mask obligation mouth-protection, \#mouth-protection, \#mask on, \#mask, \#masks,nose, obligation, mouth, wearing, mask oblgation protection, \#protective masks

\#germany, \#stayathome, \#politics, \#economy, \#health, \#crisis, \#virus, \#merkel, \#zdf, \#society, \#exit strategy, \#media, \#mask obligation, \#lanz, \#solidarity

april, may, start, schools, middle, \#stayathome, shops, bavaria, march, holiday, loosening, monday, \#lockdown, august, measures

\#stayathome, \#youtube, \#twitch, \#twitchde, \#gaming, \#streamer, fun, \#livestream, \#live, \#letsplay, \#stream, \#streaming, \#video, \#twitchstreamer, chanel

\#bundesliga, \#kurz, football, \#dfl, \#ischgl, \#övp, \#tirol, \#soccer, \#ghost games, \#austria, \#gruenen, austria, \#kogler, \#turquoise green, player

\#adidas, rent, \#deichmann, sky, \#online, mobile phone, contribution, \#rent, adidas, \#letzebuerg, \#westayathome, \#staythefuckhome, \#wewillmakeit, \#stayhealthy, \#zu, \#flattenthecurve, \#flattenthecuve, homestay, universe, \#westayat, \#staysafe, \#germanymakesmusic

shopping cart, cash desk, meter, queue, trolley, signature, entrance, customer, minimum distance, gloves, merchandise, pen, aldi, customer, salesperson

\#mask on, wearing, \#mask obligation, obligation, sewing machine, \#mask, glasses, \#mask, \#mask, \#mask, masks, mask, \#plauen, \#vogtland, \#faceshield, \#masks

\#economy, \#society, \#health, \#freedom, \#citizens, \#politics, \#exit strategy, \#media, \#science, \#exit, \#stock exchange, \#panic, \#people, \#zdf, \#crisis

august, middle, april, large public events, restaurants, hairdressers, events, may, june, hairdresser, concerts, oktoberfest, september, hotels, bars

\#streamer, \#twitchde, \#twitch, \#gaming, \#letsplay, \#twitchstreamer, \#stream, \#twitchtv, \#livestream, \#rap, \#streaming, \#youtuber, \#live, \#supportsmallstreamers, \#germanmediart

\#soccer, \#dfl, \#turquoise green, \#premiereleague, \#kogler, \#ghost games, \#dfb, football, \#oevp, \#anschober, \#platter, \#tirol, ghost games, season, soccer

\#letzebuerg, \#deichmann, \#adidas, \#hundm, adidas, reflex camera, weather, \#info, \#letzebuergesch, \#media, \#rent, \#moien, \#online, rent, h\& 
0.2 \#bayern, \#sz, \#faz, \#zeit, \#nzz, \#spiegelonline, \#oktoberfest, \#wiesn, \#zahlen, wiesn, \#söder, \#china, \#markussoeder, \#münchen, \#umwelt \#dlvö, \#hausarrest, \#wien, \#teamgoaschtig, wien, wasser, till, kamera, \#bilderrätsel, hause, \#meidling, \#kurz, \#wienliebe \#miete, \#moien, \#online, miete, h\&

\#sz, \#nzz, \#zeit, \#spiegelonline, \#faz, \#zahlen, wiesn, \#wiesn, \#bayern, \#markussoeder, beate, \#oktoberfest, harald, \#muenchen, \#bahner

\#dlvö, \#teamgoaschtig, \#türkisgrün, \#hausarrest, \#bilderrätsel, \#meidling, till, \#wienliebe, kamera, chuck, norris, \#rammstein, \#quarantäne, joggis, \#maisach \#hundm, \#info, \#news, \#media, landlord

\#bayern, \#sz, \#faz, \#zeit, \#nzz, \#spiegelonline, \#oktoberfest, \#wiesn, \#numbers, wiesn, \#söder, \#china, \#markussoeder, \#münchen, \#environment \#quarantine, \#turquoise green, \#dlvö, \#house arrest, \#wien, \#teamgoaschtig, vienna, water, till, camera, \#picture puzzle, home, \#meidling, \#kurz, \#love vienna

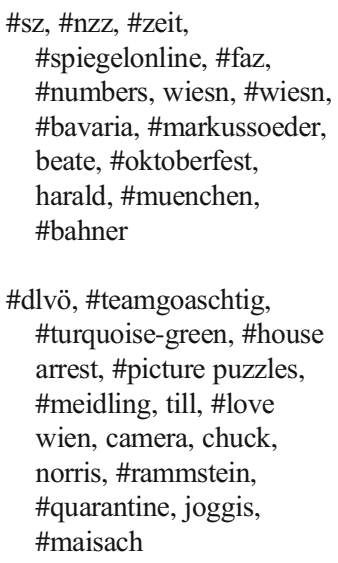

\#dlvö, \#teamgoaschtig, \#turquoise-green, \#house arrest, \#picture puzzles, \#meidling, till, \#love wien, camera, chuck, norris, \#rammstein, \#quarantine, joggis, \#maisach

20 top words per topic shown; ${ }^{\mathrm{a}}$ Topic labels were only assigned to topics with significant association with an emotion; ${ }^{\mathrm{b}}$ Proportion of all tweets; ${ }^{\mathrm{c}}$ Most probable words per topic; ${ }^{\mathrm{d}}$ Words with highest FREX scores per topics, i.e. most probable words weighted by their exclusivity for a given topic

\begin{abstract}
Authors contribution Both Anette Kersting and Franz Hanschmidt contributed to the study conception and design. Material preparation, data collection and analysis were performed by Franz Hanschmidt. The first draft of the manuscript was written by Franz Hanschmidt and both authors commented on previous versions of the manuscript. Both authors read and approved the final manuscript.
\end{abstract}

Funding Open Access funding enabled and organized by Projekt DEAL.

Data availability Unique identifiers of tweets which may be used to retrieve the full content of tweets included in the analyses are available from the authors upon request.

Code availability The code underlying the statistical analyses is available from the first author on request.

\section{Declarations}

Conflict of interest The authors declare that they have no conflict of interest.

Ethics approval Only data available within the public domain was analysed and anonymity was ensured by presenting data in aggregated form only. Thus, no ethics approval was necessary.

\section{Consent to participate Not applicable.}

Consent for publication Not applicable.

Open Access This article is licensed under a Creative Commons Attribution 4.0 International License, which permits use, sharing, adaptation, distribution and reproduction in any medium or format, as long as you give appropriate credit to the original author(s) and the source, provide a link to the Creative Commons licence, and indicate if changes were made. The images or other third party material in this article are included in the article's Creative Commons licence, unless indicated otherwise in a credit line to the material. If material is not included in the article's Creative Commons licence and your intended use is not permitted by statutory regulation or exceeds the permitted use, you will need to obtain permission directly from the copyright holder. To view a copy of this licence, visit http://creativecommons.org/licenses/by/4.0/.

\section{References}

Abd-Alrazaq A, Alhuwail D, Househ M, Hamdi M, Shah Z (2020) Top concerns of tweeters during the COVID-19 pandemic: infoveillance study. J Med Internet Res 22(4):e19016. https://doi.org/10.2196/ 19016

Asmundson GJG, Taylor S (2020) How health anxiety influences responses to viral outbreaks like COVID-19: what all decisionmakers, health authorities, and health care professionals need to know. J Anxiety Disord 71:102211. https://doi.org/10.1016/j. janxdis.2020.102211

Betsch C, Korn L, Felgendreff L, Eitze S, Schmid P, Sprengholz P, Wieler L, Schmich P, Stollorz V, Ramharter M, Bosnjak M, Omer SB, Thaiss H, de Bock F, von Rüden U, Crockett M, Krauth C, Brockmann D, Schlosser F (2020) German COVID-19 snapshot monitoring (COSMO) - Welle 9 (28.04.2020). PsychArchives. https://doi.org/10.23668/psycharchives.2904

Bischof JM, Airoldi EM (2012) Summarizing topical content with word frequency and exclusivity. In: Proceedings of the 29th international conference on machine learning. p 9-16. https://dl.acm.org/doi/10. $5555 / 3042573.3042578$

Brooks SK, Webster RK, Smith LE, Woodland L, Wessely S, Greenberg N, Rubin GJ (2020) The psychological impact of quarantine and how to reduce it: rapid review of the evidence. Lancet 395(10227):912-920. https://doi.org/10.1016/S0140-6736(20)30460-8

Bruns A, Stieglitz S (2014) Twitter data: what do they represent? IT Inform Technol 56(5):240-245. https://doi.org/10.1515/itit-20141049

Budhwani H, Sun R (2020) Creating COVID-19 stigma by referencing the novel coronavirus as the "Chinese virus" on Twitter: quantitative 
analysis of social media data. J Med Internet Res 22(5):e19301. https://doi.org/10.2196/19301

Cheng C, Barceló J, Hartnett AS, Kubinec R, Messerschmidt L (2020) COVID-19 government response event dataset (CoronaNet v.1.0). Nat Hum Behav 4:756-768. https://doi.org/10.1038/s41562-0200909-7

de Las Heras-Pedrosa C, Sánchez-Núñez P, Peláez JI (2020) Sentiment analysis and emotion understanding during the COVID-19 pandemic in Spain and its impact on digital ecosystems. Int J Environ Res Public Health 17(15):5542. https://doi.org/10.3390/ijerph17155542

Eberhard DM, Simons GF, Fennig CD (2019) Ethnologue: languages of the world. SIL International, Dallas

Hale T, Cameron-Blake E, Hallas L, Kira B, Petherick A, Phillips T, Tatlow H (2020) Oxford COVID-19 Government Response Tracker. https://ourworldindata.org/grapher/covid-stringencyinde $\mathrm{x}$ ?tab $=$ chart \& time $=2020-01-22.1$ atest $\&$ country $=$ CHE DEU AUT. Accessed 12 Dec 2020

Han X, Wang J, Zhang M, Wang X (2020) Using social media to mine and analyze public opinion related to COVID-19 in China. Int J Environ Res Public Health 17(8):2788. https://doi.org/10.3390/ ijerph17082788

Hsiang S, Allen D, Annan-Phan S, Bell K, Bolliger I, Chong T, Druckenmiller H, Huang LY, Hultgren A, Krasovich E, Lau P, Lee J, Rolf E, Tseng J, Wu T (2020) The effect of large-scale anticontagion policies on the COVID-19 pandemic. Nature 584:262 267. https://doi.org/10.1038/s41586-020-2404-8

Jimenez-Sotomayor MR, Gomez-Moreno C, Soto-Perez-de-Celis E (2020) Coronavirus, ageism, and Twitter: an evaluation of tweets about older adults and COVID-19. J Am Geriatr Soc 68:1661-1665. https://doi.org/10.1111/jgs.16508

John Hopkins University (2020) COVID-19 Map. https://coronavirus. jhu.edu/map.html. Accessed 25 June 2020

Lin Y, Hu Z, Alias H, Wong LP (2020) Knowledge, attitudes, impact, and anxiety regarding COVID-19 infection among the public in China. Front Public Health 8:236. https://doi.org/10.3389/fpubh. 2020.00236

Lipsitch M, Swerdlow DL, Finelli L (2020) Defining the epidemiology of Covid-19 - studies needed. N Engl J Med 382(13):1194-1196. https://doi.org/10.1056/NEJMp2002125

Luo M, Guo L, Yu M, Jiang W, Wang H (2020) The psychological and mental impact of coronavirus disease 2019 (COVID-19) on medical staff and general public - a systematic review and meta-analysis. Psychiatry Res 291:113190. https://doi.org/10.1016/j.psychres. 2020.113190

Lwin MO, Lu J, Sheldenkar A, Schulz PJ, Shin W, Gupta R, Yang Y (2020) Global sentiments surrounding the COVID-19 pandemic on Twitter: analysis of Twitter trends. JMIR Public Health Surveill 6(2):e19447. https://doi.org/10.2196/19447

Martin F, Johnson M (2015) More efficient topic modelling through a noun only approach. In: Proceedings of the Australasian language technology association workshop. pp 111-115. https://www. aclweb.org/anthology/U15-1013

Meier T, Boyd RL, Pennebaker JW, Mehl MR, Martin M, Wolf M, Horn AB (2019) "LIWC auf Deutsch": the development, psychometrics, and introduction of DE-LIWC2015. Center for Open Science. https://doi.org/10.31234/osf.io/uq8zt

Mellon J, Prosser C (2017) Twitter and Facebook are not representative of the general population: political attitudes and demographics of British social media users. Res Polit 4(3):205316801772000. https://doi.org/10.1177/2053168017720008

Mertens G, Gerritsen L, Duijndam S, Salemink E, Engelhard IM (2020) Fear of the Coronavirus (COVID-19): predictors in an online study conducted in March 2020. J Anxiety Disord 74:102258. https://doi. org/10.1016/j.janxdis.2020.102258

Mimno D, Wallach H, Talley E, Leenders M, McCallum A (2011) Optimizing semantic coherence in topic models. In: Proceedings of the 2011 Conference on Empirical Methods in Natural Language Processing. p 262-272. https://dl.acm.org/doi/10.5555/ 2145432.2145462

Pennebaker JW, Boyd RL, Jordan K, Blackburn K (2015) The development and psychometric properties of LIWC2015. University of Texas at Austin, Austin. http://hdl.handle.net/2152/31333

R Core Team (2019) R: a language and environment for statistical computing. R Foundation for Statistical Computing, Vienna. https:// www.r-project.org/

Roberts ME, Stewart BM, Tingley D (2019) Stm: an R package for structural topic models. J Stat Softw 91(1):1-40. https://doi.org/10. 18637/jss.v091.i02

Rufai SR, Bunce C (2020) World leaders' usage of Twitter in response to the COVID-19 pandemic: a content analysis. J Public Health (Oxf) 42:510-516. https://doi.org/10.1093/pubmed/fdaa049

Saltzman LY, Hansel TC, Bordnick PS (2020) Loneliness, isolation, and social support factors in post-COVID-19 mental health. Psychol Trauma Theory Res Pract Policy 12:S55-S57. https://doi.org/10. $1037 /$ tra0000703

Sonnenschein AR, Hofmann SG, Ziegelmayer T, Lutz W (2018) Linguistic analysis of patients with mood and anxiety disorders during cognitive behavioral therapy. Cogn Behav Ther 47(4):315-327. https://doi.org/10.1080/16506073.2017.1419505

Stevens G, O’Donnell VL, Williams L (2015) Public domain or private data? Developing an ethical approach to social media research in an inter-disciplinary project. Educ Res Eval 21(2):154-167. https://doi. org/10.1080/13803611.2015.1024010

Su Y, Xue J, Liu X, Wu P, Chen J, Chen C, Liu T, Gong W, Zhu T (2020) Examining the impact of COVID-19 lockdown in Wuhan and Lombardy: a psycholinguistic analysis on Weibo and Twitter. Int $\mathrm{J}$ Environ Res Public Health 17(12):4552. https://doi.org/10.3390/ ijerph17124552

Tasnim S, Hossain MM, Mazumder H (2020) Impact of rumors and misinformation on COVID-19 in social media. J Prev Med Public Health = Yebang Uihakhoe chi 53(3):171-174. https://doi.org/10. 3961/jpmph.20.094

Teufel M, Schweda A, Dörrie N, Musche V, Hetkamp M, Weismüller B, Lenzen H, Stettner M, Kohler H, Bäuerle A, Skoda EM (2020) Not all world leaders use Twitter in response to the COVID-19 pandemic: impact of the way of Angela Merkel on psychological distress, behaviour and risk perception. J Public Health (Oxf) 42:644-646. https://doi.org/10.1093/pubmed/fdaa060

Wang C, Pan R, Wan X, Tan Y, Xu L, McIntyre RS, Choo FN, Tran B, Ho R, Sharma VK, Ho C (2020) A longitudinal study on the mental health of general population during the COVID-19 epidemic in China. Brain Behav Immun 87:40-48. https://doi.org/10.1016/j. bbi.2020.04.028

World Health Organization (2020) WHO timeline - COVID-19. https:// www.who.int/news-room/detail/27-04-2020-who-timeline\%2D\% 2D-covid-19. Accessed 25 June 2020

Yan X, Guo J, Lan Y, Cheng X (2013) A biterm topic model for short texts. In: Schwabe D (ed) Proceedings of the 22nd international conference on the world wide web: May 13-17, 2013, Rio de Janeiro, Brazil. ACM, New York. https://doi.org/10.1145/ 2488388.2488514

Zhang Y, Ma ZF (2020) Impact of the COVID-19 pandemic on mental health and quality of life among local residents in Liaoning Province, China: a cross-sectional study. Int J Environ Res Public Health 17(7):2381. https://doi.org/10.3390/ijerph17072381

Publisher's note Springer Nature remains neutral with regard to jurisdictional claims in published maps and institutional affiliations. 